This is a revised personal version of the text of the final journal article, which is made available for scholarly purposes only, in accordance with the journal's author permissions. The full citation is:

S. Heaven, A.C. Lock, L.N. Pak and M.K. Rspaev (2003) " Waste stabilisation ponds in extreme continental climates: a comparison of design methods from the USA, Canada, northern Europe and the former Soviet Union ", Water Science \& Technology Vol 48 No 2 pp 25-33 @ IWA Publishing 2003

http://www.iwaponline.com/wst/04802/wst048020025.htm

\title{
Waste Stabilisation ponds in extreme continental climates: a comparison of design methods from the USA, Canada, northern Europe and the former Soviet Union
}

\author{
S. Heaven*, A. C. Lock*, L. N. Pak**, M. K. Rspaev** \\ * Department of Civil \& Environmental Engineering, University of Southampton, Britain. \\ ** BG Chair of Environmental Technology, Almaty Institute of Power Engineering \& Telecommunications, \\ Kazakhstan.
}

\begin{abstract}
The paper presents a brief review of the application of WSPs in extreme climates where ice formation occurs during winter. Design standards and methods are compared and different systems are described. Design equations developed by the US EPA and normative standards from the former Soviet Union are compared in a simple example using typical wastewater and performance characteristics. The results are similar except at low temperatures, where the Soviet method can give pond depths outside the prescribed limits. The paper examines construction and operational aspects of extreme climate WSPs, comparing North American, Northern European and Russian standards. It considers why WSP systems have not been widely adopted in Russia and the NIS, and looks at the advantages these systems may have in countries in economic transition.
\end{abstract}

Keywords Waste stabilisation ponds, design methods, former Soviet Union, extreme climates

\section{INTRODUCTION}

Waste stabilisation ponds (WSPs) are potentially an appropriate and effective means of wastewater treatment in many parts of the former Soviet Union. The availability of large areas of land is not a problem, while low operating costs and lack of dependence on power supplies, mechanical equipment or imported components are a major advantage in current economic conditions. In the southern republics and Central Asia in particular, WSPs are attractive because of their ability to treat wastewater to standards appropriate for re-use in agriculture, in a region where water resources are scarce. Considerable research was carried out in the Soviet period on the performance of WSPs, and state normative documents and regulations exist. In spite of this, WSPs are not widely used in the former Soviet Union for treatment of either domestic or industrial wastewaters. Possible reasons are the fact that they are often seen as low-technology option suitable only for small settlements or for tertiary wastewater treatment, and a lack of familiarity with recent world practice. This paper compares recommended design and operational practices for WSPs in some of the main cold climate regions: the USA, Canada, northern Europe and the former Soviet Union. Three related areas are considered: process design, structural design and operating procedures. The paper looks at some differences in design standards and approaches, and the implications of these for introduction of WSPs in the New Independent States (NIS). 
Design guides and standards: A key document for design of WSPs in North America and elsewhere is the US Environmental Protection Agency's design manual (US EPA, 1983). In Canada, design standards are not consolidated in a single document, but central and provincial authorities have published a wealth of guidance material, and there is naturally a significant degree of exchange with the USA. Northern Europe has few recent guidelines, reflecting the falling number of WSP systems. Design and construction in the former Soviet Union is regulated by documents known as the Construction Norms and Regulations (SNiPs). WSPs are covered in SNiP 2.04.03-85 on Water Drainage: External Networks and Structures.

\section{PROCESS DESIGN}

The pond types used in typical WSP systems in extreme continental climates are essentially the same as those in temperate or tropical areas: there are several possible classifications, but a common one is anaerobic, facultative and storage/maturation ponds. The main difference is in the discharge mode. The majority of warm climate ponds operate as continuous discharge systems where treated effluent discharges into a watercourse at a rate dependent on the inflow. In cold and extreme climates intermittent discharge systems are more common, in which the wastewater is retained for long periods and is released once or twice a year, usually in spring and/or autumn. The long retention time is based on the fact that in winter the degree of treatment and the capacity of the receiving watercourse are sharply reduced, and ice cover may make discharge impossible. A third category of total containment ponds exists, usually in regions where evaporation is greater than precipitation: these do not discharge to a water body. Containment ponds are relatively rare in North America but are common in the former Soviet Union, especially for industrial enterprises.

\section{Anaerobic and storage/maturation ponds}

Design of anaerobic ponds is generally based on hydraulic retention time (HRT) and depth, as in warm climates. Dawson and Grainge (1969) suggested depths of $3.05-7.62 \mathrm{~m}$ for short-retention, dominantly anaerobic ponds in northern latitudes, to conserve heat and allow for additional sludge accumulation. Schneiter et al. (1983) give values for sludge accumulation in different conditions. More recently, Environment Canada recommended depths of 3-5 $\mathrm{m}$ and a minimum HRT of 2-5 days (Environment Canada, 1996). In the former Soviet Union there is no mention of anaerobic ponds in the section of SNiP 2.04.0385 on WSPs. Vinberg et al. (1966) note the need to conserve heat and reduce evaporation and suggest depths of 2.4-3.6 m, but these values refer to work done in the USA. Lukinykh et al. (1978) recommend depths of up to $3 \mathrm{~m}$ and a HRT of 24 hours. Abdrashitova et al. (2001) suggest the anaerobic pond should be designed to balance the rates of accumulation and destruction of organic solids, in order to reduce the frequency of de-sludging: the proper sizing of this unit therefore needs to be resolved and will depend on factors such as the temperature and duration of the warmer months.

Design of the storage/maturation pond for an intermittent discharge system is also based on HRT time, determined by climatic conditions (eg. the period of ice cover) and the frequency of discharge. The most common values are 12 and 6 months corresponding to once and twice-yearly discharge, sometimes with a safety margin of 2-3 months to allow for conditions in the receiving watercourse. The maximum recommended working depth of storage lagoons is generally around $2.5 \mathrm{~m}$ (Heinke et al., 1991; Prince et al., 1994). This is greater than the optimum of $1.5 \mathrm{~m}$ for facultative ponds, since treatment is not the main purpose (Prince et al., 1995), and since for much of the year ponds contain treated water with a low biochemical oxygen demand (BOD) (Abdrashitova et al., 2001). 


\section{Facultative ponds: design equations and models}

The US EPA manual (US EPA, 1983) gives sample calculations for five design methods for facultative ponds: Areal Loading Rate, Gloyna, Marais-Shaw, Plug Flow and WehnerWilhelm. The Marais-Shaw Equation was developed for warm climates, and is less suitable at cold temperatures. The remaining methods give reasonable results, but choice of design coefficients can be problematic. The Areal Loading Rate is simplest in this respect, and is often preferred for this reason. Design equations for Areal Loading and Plug Flow methods are shown in Table 1. Pond depth requirements vary in different states. Gloyna's equation uses $1.5 \mathrm{~m}$ for areas with significant seasonal temperature variation and $1.5-2 \mathrm{~m}$ for severe climates, but $3 \mathrm{~m}$ is accepted elsewhere. These values include sludge storage and ice formation, and need to be adjusted for process calculations. Many states also specify a minimum operating depth of $0.6 \mathrm{~m}$. There are no rational or empirical models specifically for the design of intermittent discharge WSPs, but methods for facultative ponds can be adapted by allowing for the extra storage volume required (US EPA, 1975). The US EPA manual comments that conservative loading rates for severe climates may mean retention times are longer than actually needed.

Table 1 Plug Flow and SNiP 2.04.03-85 design equations

Areal loading rate for average winter air temperature $<0^{\circ} \mathrm{C}$ (based on US EPA, 1983)

$\mathrm{BOD}_{5}$ loading $=11-22 \mathrm{~kg} \mathrm{ha}^{-1}$ day ${ }^{-1}$ depending on severity of climate. $\mathrm{BOD}_{5}$ loading on first pond limited to $40 \mathrm{~kg} \mathrm{ha}^{-1} \mathrm{day}^{-1}$. HRT $=120-180$ days, depending on period of ice cover and discharge conditions.

\section{Plug Flow (based on US EPA, 1983)}

$\frac{C_{e}}{C_{o}}=e^{-k_{p} t}$

$\mathrm{C}_{\mathrm{e}}=$ effluent $\mathrm{BOD}_{5}, \mathrm{mg} \mathrm{I}^{-1} ; \mathrm{C}_{0}=$ influent $\mathrm{BOD}_{5}, \mathrm{mg} \mathrm{I}^{-1} ; k_{\mathrm{p}}=$ plug flow 1 st-order reaction rate day ${ }^{-1} ; \mathrm{t}=$ $\mathrm{HRT}$, days. $\mathrm{BOD}_{5}$ loading on first pond limited to $40 \mathrm{~kg} \mathrm{ha}^{-1} \mathrm{day}^{-1}$. Temperature adjustment $k_{\mathrm{pT}}=$ $k_{\mathrm{p} 20}(1.09)^{\mathrm{T}-20}$ where $\mathrm{T}=$ minimum operating water temperature ${ }^{\circ} \mathrm{C} . \mathrm{k}_{\mathrm{p}}$ varies with $\mathrm{BOD}$ loading rate as shown:

$\begin{array}{llllll}\mathrm{BOD}_{5} \mathrm{~kg} \mathrm{ha}^{-1} \text { day }^{-1} & 22 & 45 & 67 & 90 & 112\end{array}$

$\begin{array}{llllll}\mathrm{K}_{\mathrm{p} 20} \text { day }^{-1} & 0.045 & 0.071 & 0.083 & 00.096 & 0.129\end{array}$

\section{SNiP 2.04.03-85}

$$
t_{\text {lag }}=\frac{1}{K_{\text {lag }} k} \sum_{1}^{N-1} \ln \frac{L_{e n}}{L_{e x}}+\frac{1}{K_{\text {lag }}^{\prime} k^{\prime}} \ln \frac{L_{e n}^{\prime}-L_{f i n}}{L_{e x}^{\prime}-L_{f i n}} \text { (2) }
$$

$\mathrm{t}_{\mathrm{lag}}=\mathrm{HRT}$, days; $\mathrm{N}=$ no. of pond stages, $\mathrm{K}_{\text {lag }}=$ volumetric use factor $=0.8-0.9$ for length: width ratio $20: 1,0.35$ for natural reservoirs, interpolated for intermediate values; $L_{e n}=$ influent $B O D_{u}, \mathrm{mg} \mathrm{l}^{-1} ; L_{e x}$ $=$ effluent $\mathrm{BOD}_{\mathrm{u}}, \mathrm{mg} \mathrm{I}^{-1} ; \mathrm{L}_{\text {fin }}=$ residual $\mathrm{BOD}_{\mathrm{u}}=2-3 \mathrm{mg} \mathrm{l}^{-1}$ in summer, $5 \mathrm{mg} \mathrm{l}-1$ in bloom and $1-2 \mathrm{mg} \mathrm{I}-1$ in winter; $k=$ oxygen consumption rate constant $=$ experimentally defined or 0.1 day $^{-1}$ for intermediate ponds and 0.07 day $^{-1}$ for final pond, at $20^{\circ} \mathrm{C}$. Water temperature adjustment $k_{\mathrm{T}}=k_{20}\left(1.047^{\mathrm{T}-20}\right)$ for $5-30^{\circ} \mathrm{C}$ and $k_{\mathrm{T}}=k_{20}\left(1.12(\mathrm{~T}+1)^{-0.022}\right)^{\mathrm{T}-20}$ for $0-5^{\circ} \mathrm{C}$. Symbols marked 'apply to the final pond.

$$
F_{\text {lag }}=\frac{Q C_{a}\left(L_{e n}-L_{e x}\right)}{K_{\text {lag }}\left(C_{a}-C_{e x}\right) r_{a}}(3) ; \quad H_{\text {lag }}=\frac{K_{\text {lag }}\left(C_{a}-C_{e x}\right) r_{a} t_{\text {lag }}}{C_{a}\left(L_{e n}-L_{e x}\right)} \quad\left(=Q \frac{t_{\text {lag }}}{F_{\text {lag }}}\right)
$$

$F_{\text {lag }}=$ pond surface area, $\mathrm{m}^{2} ; \mathrm{Q}=$ wastewater flow, $\mathrm{m}^{3}$ day ${ }^{-1} ; \mathrm{C}_{\mathrm{a}}=$ solubility of oxygen in water, $\mathrm{mg} \mathrm{I}^{-1}$; $C_{e x}=$ oxygen concentration to be maintained in effluent $=2 \mathrm{mg} \mathrm{l}^{-1}$ (Stroyizdat 1981b); $r_{a}=$ atmospheric aeration at unit oxygen deficiency $=3-4 \mathrm{~g} \mathrm{~m}^{-2}$ day $^{-1} ; \mathrm{H}_{\mathrm{lag}}=$ depth of naturally aerated pond, $\mathrm{m}$.

In Canada, Thirumurthi also considered the available analytical and empirical models (Thirumurthi, 1969; Environment Canada, 1987). In addition to those described above, design models potentially suitable for cold temperature application include McGarry and Pescod's empirical method with an allowance for temperature; the Non-Linear Multiple Regression method; Thirumurthi approximate and dispersed plug flow methods; the Dissanayake equation and the Indian empirical method (see Table 1). Again these do not 
apply directly to intermittent discharge lagoons. Smith and Finch (1983) also discuss design and modelling approaches, but conclude that no one method is adequate and simpler methods based on retention time are likely to perform as well as more complex ones. In practice design in Canada is generally based on a combination of surface loading rate and HRT (Heinke et al., 1991), with each province specifying design standards. Pond depths are similar to those in USA, with a recommended minimum of $1.2 \mathrm{~m}$ (Environment Canada, 1996).

In Norway, the Environmental Protection Board suggested a 7-day BOD loading of $3.5 \mathrm{~g} \mathrm{~m}^{-2}$ day $^{-1}$, and a depth of 1.2-1.8 m (SFT, 1983), while Sweden formerly used a design value of $10 \mathrm{~m}^{2}$ person $^{-1}$ (Hanæus, 1991). The widespread adoption in Scandinavia of chemical precipitation methods, however, means there have been no recent developments in WSP design theory (TemaNord, 1995).

For WSPs in the former Soviet Union, SNiP 2.04.03-85 specifies that wastewater for full treatment by natural aeration must have an ultimate BOD $\left(\mathrm{BOD}_{\mathrm{u}}\right)$ of $<200 \mathrm{mg} \mathrm{l}^{-1}$, or $<500$ $\mathrm{mg} \mathrm{l}^{-1}$ for artificially aerated ponds. For tertiary treatment the limits are 25 and $50 \mathrm{mg}^{-1}$. If the influent $\mathrm{BOD}_{\mathrm{u}}$ is $>500 \mathrm{mg} \mathrm{l}^{-1}$ preliminary treatment is required. The design equations, shown in Table 1, are based on BOD removal kinetics but there are a number of differences from the Plug Flow method used in the USA and Canada. The rate constant $k$ for oxygen consumption at $20{ }^{\circ} \mathrm{C}$ is taken as $0.1 \mathrm{day}^{-1}$ for intermediate ponds and $0.07 \mathrm{day}^{-1}$ in the final section. The temperature correction for $k$ differs, particularly below $5{ }^{\circ} \mathrm{C}$ where the physical properties of water are different. A factor for pond length-to-width ratio is introduced, and a residual $\mathrm{BOD}_{\mathrm{u}}$ is assumed in the final pond. The main difference is in the method of determining the surface area, which is based on atmospheric reaeration. Pond depth is then calculated from the surface area and HRT time. The working depth of the pond is limited to $0.5 \mathrm{~m}$ for an initial $\mathrm{BOD}_{\mathrm{u}}$ of $>100 \mathrm{mg} \mathrm{l}^{-1}$ and $1 \mathrm{~m}$ for $\mathrm{BOD}_{\mathrm{u}}<100 \mathrm{mg} \mathrm{l}^{-1}$. The same design basis is used for tertiary ponds, with coefficients adjusted accordingly.

The SNiP and US EPA Plug Flow methods were compared, with $\mathrm{BOD}_{\mathrm{u}}$ values converted to $\mathrm{BOD}_{5}$ by a factor of 1.47 (Arceivala, 1999). Figure 1 shows the results for an influent $\mathrm{BOD}_{\mathrm{u}}$ $\left[\mathrm{BOD}_{5}\right]$ of $200[136] \mathrm{mg} / \mathrm{l}$, an effluent $\mathrm{BOD}_{\mathrm{u}}\left[\mathrm{BOD}_{5}\right]$ of 30 [20] $\mathrm{mg} \mathrm{l}^{-1}$, and a flow of $1000 \mathrm{~m}^{3}$ day $^{-1}$ treated in two serial ponds with water temperatures from $0-9{ }^{\circ} \mathrm{C}$. SNiP calculations were repeated for $\mathrm{K}_{\mathrm{lag}}=0.35$ and 0.85 . For the purpose of comparison surface areas were taken as volume divided by depth, without allowance for side slopes etc. Design effluent $\mathrm{BOD}_{\mathrm{u}}$ values for the first SNiP pond in the example shown are based on the US EPA value. The US EPA values for HRT generally lie between the SNiP values, although the upper value diverges sharply below $5{ }^{\circ} \mathrm{C}$ (Figure 1a). In the US EPA system, however, the surface area is calculated based on a fixed depth: in the SNiP the depth can theoretically vary, but at low water temperatures the calculated values are much greater than the imposed limits (see Figure 1b). If surface area is recalculated based on required depth it increases significantly, as shown in Figure 1c. Increasing the number of ponds improves depth values for intermediate sections but does not solve the problem. In practice at low temperatures depth limits are a controlling factor, and give more conservative values than the USE PA method. Figure 1d shows comparative $\mathrm{k}$ values: it should be remembered that $\mathrm{SNiP}$ values are multiplied by $\mathrm{K}_{\mathrm{lag}}$.

Neither the US EPA nor the SNiP plug flow equations are particularly user-friendly for the design of naturally aerated ponds for full treatment of wastewater at low temperatures; but several features of the SNiP, such as the low BOD loadings and restricted depths, indicate 
that it is mainly intended for design of tertiary treatment and shallow ponds with full-depth light penetration. The SNiP itself states that WSPs can be used for full or tertiary treatment, but standard textbooks and guidelines for interpretation of the SNiP and its predecessors often omit WSPs (Kolobanov et al. 1977; VODGEO, 1990). Samokhin (Stroyizdat, 1981b) provides a design nomograph, but Laskov et al. (1987) give no guidance on calculation methods, and simply suggest a 60\% BOD removal efficiency in each pond. On the other hand several sources state that WSPs are only suitable for warm climates or for use in warm periods of the year (Stroyizdat, 1981a; VNII-SIS, 1987b). Others only mention tertiary treatment, or say WSPs can operate at low temperatures, but recommend shallow ponds that can obtain oxygen from photosynthesis without the risk of stratification (Alferova et al., 1974; Lukinykh et al., 1978). A great deal of work has been done in the former Soviet Union on sophisticated high-rate and contact pond systems (Vinberg et al., 1966; VNII-SIS, 1987a; VNII-SIS, 1987b; Skirdov and Almaneyfi, 1999). Vinberg's work in particular focuses on the potential contribution from photosynthetic oxygen, and is fully aware of all the research carried out in the West on this theme. In spite of this, however, official sources state that photosynthetic aeration should be considered only as a reserve source of oxygen (Stroyizdat, 1981b).

1a: HRT


1b: Pond depths

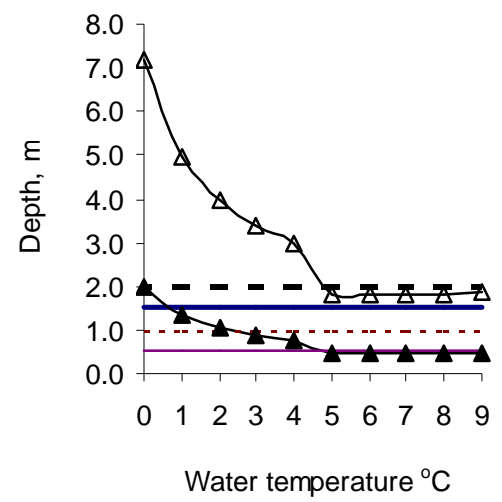

1d: $k$ Values

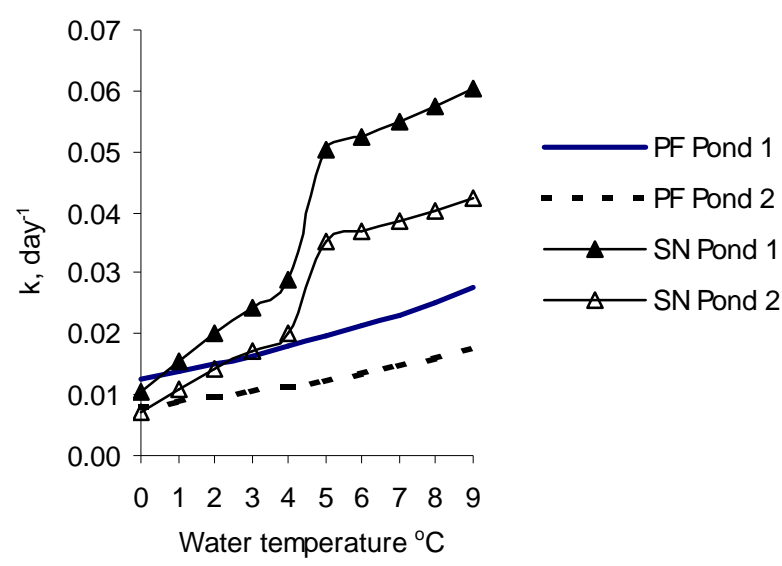

Figure 1 Comparison of designs from US EPA Plug Flow and SNiP 2.04.03-85 methods 


\section{STRUCTURE AND CONFIGURATION}

Configuration. SNiP 2.03.04-85 says WSP systems should consist of at least two parallel lines of 3-5 sections each, with the option of isolating any section for cleaning or repair. The length:width ratio for naturally aerated ponds should be 20:1 or more. US EPA (1983) similarly recommends at least three ponds in a treatment line, with pipework to allow parallel or series operation. Large single cells with a central inlet are not preferred, as this may reduce capacity. Much smaller length:width ratios are accepted in North America, however, with 3:1 considered as adequate (Environment Canada, 1985 and 1996). Research on temperate climate ponds (Pearson et al., 1995) also suggests that length:width ratios have little effect on effluent quality. Prince et al. (1994, 1995a and b) carried out a major review of the effect of WSP system configuration on performance, based on data from Alberta, Canada, and concluded that the most robust system consisted of four anaerobic ponds, one facultative pond and one storage pond. This system is often described as $4 \mathrm{~S}, 1 \mathrm{~T}, 1 \mathrm{~L}$, where $\mathrm{S}$ refers to sedimentation, $\mathrm{T}$ to treatment and $\mathrm{L}$ to lagoon storage, and is now widely adopted for design purposes.

Ice. Ponds in extreme climates need additional volume for ice. According to SNiP 2.04.0385 , if the pond may freeze in winter the depth should be increased by $0.5 \mathrm{~m}$. In northern Sweden ice thickness in lakes can reach $1.2 \mathrm{~m}$ but is less in ponds due to the warm influent (Hanæus, 1991). In WSPs in the central mountains, ice reaches $0.6 \mathrm{~m}$ deep and melts in a period of 3-4 weeks, imposing a hydraulic and BOD load. A common solution is to install an adjustable outlet weir, so that the water volume remains constant. In northern Canada ice can reach $2 \mathrm{~m}$ thick, presenting major problems for mechanical equipment and lining systems. Protection of overflow pipes from ice loading and heave is a special problem due to their high level (Environment Canada, 1987).

Construction and lining. WSPs in the former Soviet Union may be constructed on lowpermeability ground, or may be lined. Construction of liners is regulated by SN 551-82 (1982). Engineering use of plastics is still less widespread in the former Soviet Union than elsewhere, and standards for thickness and jointing of materials are less stringent than in the West; but construction details are broadly similar to those shown by the US EPA (1983). Merrill and Stephl (1996) describe a case of liner failure. Ponds in Scandinavia are rarely lined (Hanæus, 1991). To prevent plant growth and erosion, inner slopes should be covered with concrete slabs, asphalt, plastic membrane or stones to $0.5 \mathrm{~m}$ above water level and to maximum light penetration depth (usually $1 \mathrm{~m}$ ) below (Stroyizdat 1981b; VNII-SIS 1987a, Environment Canada 1996). Former Soviet Union guidelines suggest freeboard of $0.5 \mathrm{~m}$ for areas up to $0.5 \mathrm{ha}$, and $0.7 \mathrm{~m}$ for more than 0.5 ha (VNII-SIS 1987a). Heinke et al. (1991) recommend $1 \mathrm{~m}$ freeboard in northern WSPs, however, to allow for frost heave and ice movement. Extensive work has been done in Canada and elsewhere to establish guidelines for construction in permafrost regions (Environment Canada, 1985).

Hydraulics and pipework: The need to position and design inlet and outlet structures to minimise short-circuiting is recognised everywhere. Research carried out in temperate climates by Peña et al. (2000) suggests this factor may be more important for anaerobic ponds than has been realised. SNiP 2.04.03-85 requires the transfer pipe between pond sections to be $0.3-0.5 \mathrm{~m}$ above the bed, with an upturned end, in order to prevent erosion. Treated water must be discharged 0.15-0.2 times the depth of the pond below the water level or lower surface of ice. Structures that allow draw-off at different levels are recommended, as is heating of pumpwells and pipelines in the north (Stroyizdat, 1981a; VNII-SIS, 1987a). 
For the USA and Canada, the Cold Regions Utilities Monograph (1996) provides design details for a wide range of cold climate systems including control structures and pipe connections. In Europe and North America, baffling within the pond is suggested to prevent stratification and reduce short-circuiting, but design of baffle systems for cold climates is difficult due to ice loading (Hanæus, 1991).

Location: All countries recommend that WSPs are sited downwind of inhabited areas with respect to the prevailing wind in the warm season. The direction of wastewater flow should be perpendicular to this wind direction to reduce short-circuiting and to enhance mixing, although there is debate about the benefits of stratification. Winter wind direction is also an important factor in snow-drifting: a snow layer improves insulation, reduces ice thickness and accelerates the spring warm-up (Environment Canada 1987; Heinke et al., 1991), but cuts down light, reduces disinfection and prevents photosynthetic aeration (VNII-SIS 1987b; Environment Canada, 1996). Buffer zone widths around WSPs vary from 200 to $300 \mathrm{~m}$ in the former Soviet Union depending on the volume treated, and from 30 to $300 \mathrm{~m}$ in Canada depending on pond type and property type (SNiP 2.04.03-85, 1996; Environment Canada, 1987 and 1996). In Sweden covered plants are recommended in areas with temperatures of less than $-10{ }^{\circ} \mathrm{C}$ for more than 30 days (Ulmgren, 1974).

\section{OPERATION AND MAINTENANCE}

In the USA and Canada control of the discharge operation is seen as the most critical factor in performance of intermittent discharge WSP systems (US EPA, 1983). The operator must be provided with discharge guidelines and a recommended schedule. Pond and receiving water quality must be carefully assessed before and during discharge. The normal procedure is to isolate the section to be discharged and to measure a range of parameters including BOD, suspended solids (SS), volatile suspended solids (VSS), $\mathrm{pH}$ and dissolved oxygen (DO). Colour, turbidity, and any unusual factors are also noted. The regulatory agency is notified and its approval requested. Once approval is obtained discharge can begin, and can continue as long as the weather is favourable, DO is near or above saturation, and turbidity satisfactory. During discharge samples should be taken three times daily in the receiving water near the outlet, and analysed for DO and SS. A typical operating pattern for multiple ponds is to draw down the last two sections to $0.45-0.60 \mathrm{~m}$. Once one section is empty, discharge is interrupted while the flow is diverted into the drawn-down section and the remaining section is rested before emptying. Both spring and autumn discharge are common. Spring discharge may have the advantage of coinciding with peak flows in the receiving watercourse, and of allowing a reduction in storage volume if two annual discharges are possible. Care must be taken, however, to avoid the spring turnover period. Autumn discharges can be made when algal solids are a minimum and effluent quality at its peak, potentially providing a valuable contribution to river flows in arid or sharply continental climates. There is a growing consensus that 12 months of storage with autumn discharge provides the best results under most operating conditions. Prince et al. (1995a and b) confirmed that with a single autumn discharge the $4 \mathrm{~S}, 1 \mathrm{~T}$, 1L system can out-perform conventional plants over a wide range of parameters.

In the former Soviet Union the absence of guidelines of this type reflects the lack of familiarity with intermittent discharge operation. On the other hand, it is not uncommon for effluent discharged into total containment ponds to be subject to stringent conditions, even when there is no further release to the environment. These conditions moreover are often applied at the point of discharge into the pond, rather than to the pond contents, making no allowance for treatment processes in the pond. 
Extreme climate modifications to WSP operation include the addition of special microorganisms, a popular approach in the former Soviet Union (VNII-SIS, 1987a and b); the use of coagulants and chemical precipitation, now the dominant method in northern Europe (Ødegaard et al., 1987)

According to Soviet norms the staff input required is one qualified wastewater treatment works operator for a WSP system treating up to $400 \mathrm{~m}^{3}$ day $^{-1}, 2$ for $400-1400 \mathrm{~m}^{3}$ day $^{-1}$ and 3 for flows above $1400 \mathrm{~m}^{3}$ day $^{-1}$ (Stroyizdat, 1981b). In Canada wastewater facilities for more than 1500 persons are also required to have a qualified operator (Environment Canada, 1996).

\section{CONCLUSIONS}

Although the theory of extreme climate WSP design is less well established than for other types of wastewater treatment, there is growing consensus on empirically-based parameters. In the former Soviet Union there is a strong theoretical base, but conflicting information on the applications of WSPs and the lack of practical guidance indicate reluctance to translate this into practice. Many of the design criteria are similar, with the exception of those governing pond depth, but operational practices differ and in particular the use of intermittent discharge WSPs is rare in the former Soviet Union. The good results obtained from wellmanaged WSP systems in North America suggest, however, that this technology is appropriate for similar climatic regions. Exchanges of design models and operational experience between extreme climate regions are likely to lead to improved performance and uptake of WSPs in all areas.

\section{Acknowlegements}

The authors would like to acknowledge the support of EU INCO-Copernicus Project CT980144, INTAS KZ 96-1864, and of the BG Foundation, which allowed them to carry out this work.

\section{References}

Abdrashitova, S.A., Banks, C.J., Pak, L.N., and G.B. Koloskov. (2001) An evaluation of waste stabilisation ponds for extreme continental climates: the design of laboratory and pilot scale trials. Izvestiya Akademii Nauk, Academy of Sciences of Kazakhstan, Biological and Medical Series, 6, 20-29.

Alferova, L.A., Skirdov, I.V., Ponomarev, V.G., Hudenko, B.M., Gladkov, V.A., and Rogovskaya, Z.I. (1973) Sewage treatment in the northern areas of the USSR. In: E. Davis, ed. International Symposium on Wastewater Treatment in Cold Climates. Report EPS 3-wp-74-3. Environment Canada, Saskatoon, 64-74.

Arceivala, S. J. (1998) Wastewater treatment for pollution control. Tata McGraw-Hill, New Delhi.

Cold Regions Utilities Monograph (1996) D.W. Smith (Ed). 3rd edn, American Society of Civil Engineers/Canadian Society for Civil Engineering. ASCE, New York.

Dawson, R.N., and Grainge, J.W.. (1969) Proposed design criteria for wastewater lagoons in arctic or subarctic regions. J. Wat. Pollut. Control Fed. 41, 237-246.

Environment Canada. (1985) Sewage Lagoons in cold climates. Report EPS 4/NR/1. Technical Services Branch. Environment Canada, Ottawa.

Environment Canada. (1987) Cold Climate Sewage Lagoons. Proceedings of the 1985 Workshop, Winnipeg, Manitoba. A.R. Townshend and H. Knoll (Eds). Report EPS 3/NR/1. Environment Canada, Ottawa.

Environment Canada. (1996) Sewage lagoon design using wetlands and other upgrading technologies to achieve non-acutely toxic effluent. 2nd edition. Report DOE FRAP 1994-34. Environment Canada, Vancouver.

Hanæus, J. (1991) Wastewater treatment by chemical precipitation in ponds. PhD thesis, Lulea University of Technology, Lulea.

Heinke, G.W., Smith, D.W., and G.R. Finch. (1991) Guidelines for the planning and design of wastewater lagoon systems in cold climates. Canadian Journal of Civil Engineering 18, 556-567.

Kolobanov, S.K., Ershov, A.V., and M.E. Kigel. (1977) Design of wastewater treatment plants. (In Russian). Budivelnik, Kiev. 
Laskov, Yu.M., Voronov, Yu.V., and V.I. Kalitsun. (1987) Examples of calculation / design of wastewater installations. (In Russian). Stroyizdat, Moscow.

Lukinykh, N.A., Lipman, B.L., and V.P. Krishtul. (1978) Methods for tertiary treatment of wastewater. (In Russian). Stroyizdat, Moscow.

Merrill, K.S., and Stephl, M. (1996) Case history of a lined wastewater treatment lagoon failure. In: R. F. Carlson, ed. 8th International Conference on Cold Regions Engineering. ASCE, Fairbanks, Alaska, 518532.

Ödegaard, H., Balmer, P., and J. Hanæus. (1987) Chemical precipitation in highly loaded stabilisation ponds in cold climates: Scandinavian experiences. Wat. Sci. Tech. 19(12), 71-77.

Pearson, H.W., Mara, D.D., and H.A. Arridge. (1995) The influence of pond geometry and configuration on facultative and maturation waste stabilization pond performance and efficiency. Wat. Sci. Tech. 31(12), 129139.

Peña, M.R., Mara, D.D., and A. Sanchez. (2000) Dispersion studies in anaerobic ponds: implications for design and operation. Wat. Sci. Tech. 42 (10-11), 273-282.

Prince, D.S., Smith, D.W., and S.J. Stanley. (1994) Evaluation of lagoon treatment in Alberta. Environmental Engineering Technical Report 94-1. Department of Civil Engineering, University of Alberta, Edmonton.

Prince, D.S., Smith, D.W., and S.J. Stanley. (1995a) Performance of lagoons experiencing seasonal ice cover. Water Environment Research 67 (3), 318-326.

Prince, D.S., Smith, D.W., and S.J. Stanley. (1995b) Intermittent-discharge lagoons for use in cold regions. J Cold Regions Engineering ASCE 9(4), 183-194.

Schneiter, R.W., Middlebrooks, E.J., and R.S. Sletten. (1983) Cold region wastewater lagoon sludge accumulation. Wat. Res. 17(9) 1201-1206.

Skirdov, I.V. and Almaneyfi, A.A. (1999) Intensification of the treatment of wastewater in biological ponds. (In Russian). Water Supply and Sanitary Technology 2, 28-30.

Smith, D.W. and Finch, G.R. (1983) A critical evaluation of the operation and performance of lagoons in cold climates. Contract 14SU KE 145-2-0675. Department of Civil Engineering, University of Alberta, Edmonton.

SN 551-82. (1982) Instructions for design and construction of impermeable polyethylene liners for artificial water bodies. Gosstroi SSR, Moscow.

SNiP 2.04.03-85. (1996) Water Drainage: External Networks and Structures. Construction Norms and Regulations. (In Russian). MinStroi, Moscow.

SFT. (1983) Retningslinjer for dimensjonering av avlфpsrenseanlegg. (In Norwegian). TA-525. O.S. Nedenes and H. Rensvik (Eds). Statens Forurensningstilsyn, Oslo.

Stroyizdat. (1981a) Reference book for operation of water supply, wastewater and gas supply systems. (In Russian). S.M. Shifrin and V.D. Dmitriev (Eds). Stroyizdat, Leningrad.

Stroyizdat. (1981b) Wastewater drainage for populated places and industrial enterprises. (In Russian). V.N. Samokhin (Ed). Stroyizdat, Moscow.

TemaNord. (1995) Small Wastewater Treatment Plants. TemaNord Report 1995:650. Nordic Council of Ministers, Copenhagen.

Thirumurthi, D. (1969) Design criteria for Waste Stabilisation Ponds. J San Div ASCE 95 SA2, 311-330.

Ulmgren, L. (1974) Swedish experiences in sewage treatment. In: E. Davis, ed. International Symposium on Wastewater Treatment in Cold Climates. Report EPS 3-wp-74-3. Environment Canada, Saskatoon, 45-63.

US EPA. (1975) Wastewater treatment ponds. R 430/9-74-001. US Environmental Protection Agency, Washington DC.

US EPA. (1983) Design Manual: Municipal Wastewater Stabilization Ponds. Report 625/1-83-015, US Environmental Protection Agency, Cincinnati, Ohio.

US EPA. (1992) Manual: Wastewater Treatment / Disposal for Small Communities. Report 625/R-92-005. US Environmental Protection Agency, Cincinnati, Ohio.

Vinberg, G.G., Ostapenya, P.V., Sivko, T.N., and R.I. Levina. (1966) Biological ponds in the practice of wastewater treatment. (In Russian). Belarus Publishers, Minsk.

VNII-SIS. (1987a) Recommendations for treatment and disinfection of wastewater from populated places and from poultry enterprises in biological ponds. (In Russian). All-Union Scientific-Production Institute for Agricultural Use of Wastewater 'Progress'. Ministry of Melioration \& Water Management USSR, Moscow.

VNII-SIS. (1987b) Recommendations for construction of biological oxidation contact stabilisation (BOCS) ponds in the USSR for small populated places. (In Russian). All-Union Scientific-Research Institute for Agricultural Use of Wastewater 'Progress'. Ministry of Melioration \& Water Management USSR, Moscow.

VODGEO. (1990) Reference guide for SNiP: Design of wastewater treatment installations. (In Russian). AllUnion Complex Scientific Research and Construction Technology Institute for Water Supply, Drainage, Hydrotechnical Installations and Engineering Hydrogeology. Z.S. Shestopalov (Ed). Stroyizdat, Moscow. 